\title{
ASPECTS OF PRIVATE LAW WHICH ARE NOT ENFORCED BY THE REGULATION (EU) No 650/2012
}

\section{Nicolae}

\author{
Ioana Nicolae \\ Law Faculty, Law Departament \\ Transilvania University, Braşov, Romania \\ E-mail: ioana.nicolae@unitbv.ro
}

\begin{abstract}
A novelty element which concerns even Romanian citizens is the enforcement of Regulation (EU) no 650/2012. Although the area of enforcement of the regulation should include all aspect of civil law regarding a deceased person's patrimony, certain aspects were deliberately left out from the enforcement area of this regulation, as the questions governed by the law of companies or relating to matrimonial property regimes. To illustrate the effects of the death of an associate in a company, we will provide a short comparative presentation of the continuance of the collective society with the heirs of the deceased partner as regulated by Law no 31/1990 regarding Romanian companies as opposed to the French Civil Code. Also, our brief analysis of the Proposal for a Council regulation on jurisdiction, applicable law and the recognition and enforcement of decisions in matters of matrimonial property regimes, may shed some light on what is to come in matrimonial property regimes.
\end{abstract}

Key-words: succession, inheritance, companies, matrimonial regimes, choice of governing law, comparative law.

The regulation of succession law is different from one state to the other within the European Union, as there is no unified succession regime, thus allowing each state to enforce its own system in regard to succession, according to its notational traditions in this area; the succession regime may be one of the most stable components of civil law.

In spite of the local specifics, national tradition in regard to succession, at least within the great Roman-German system of law, have the same origin, as the two main pillars of European continental civil law - French law and German law - derive from Roman law1.

A novelty element which appears in the European continental system, which concerns Romanian citizens who own goods or have a usual residence in another member state, is the enforcement of Regulation (EU) no 650/20122 in case of succession which began on the date of August $17^{\text {th }}, 2015$ or after this date3.

The purpose of this regulation is that the citizens can organize their succession in a timely manner, mostly in regard to the law that applies to the inheritance; also, it aims to

\footnotetext{
1 See V. D. Zlătescu, Panorama of the great contemporary systems of law, „Continent XXI” Publishing House, Bucharest, 1994, p. 29.

${ }^{2}$ Regulation (EU) no 650/2012 of the European Parliament and the Council of July 4th, 2012 regarding the competence, the law which applies, the acknowledgement and execution of legal decisions and accepting and executing authentic documents regarding succession and the creation of an European heir's certificate, published in the Official Bulletin of the European Union, L 201, of 27.7.2012, p. 107-134.

${ }_{3}$ According to alignments (2) - (4) of article 83 of the Regulation, these provisions will be applied in certain situations even if the law which applies was chosen before August 17th, 2015.
} 
eliminate obstacles which prevent the free circulation of people who are faced with difficulty in exercising their own rights in regard to succession with foreign elements.

However, we must state that choosing the law which applies to succession is limited by the law of the state whose citizenship de cuius has at the time that law was chosen or at the time of death. If de cuius has several citizenships, he can choose the law of any of the states whose citizen he is at the time of choice or at the time of death.

If de cuius fails to make a valid choice, the law of the state where the deceased had its domicile at the time of death will apply; the European lawmaker's choice to establish the usual residence as a connection factor between succession and the law which regulated it is justified by the increase of citizen's mobility as well as the need to ensure a correct enforcement of European Union justice.

The area of enforcement of the regulation should include all aspect of civil law regarding a deceased person's patrimony, namely all forms of transfer of goods, rights and obligations, whether it is a voluntary action of transferring goods based on a will or an $a b$ instestat succession.

According to article 23 second alignment, the law which applies to succession, regulates the cause, time and place where inheritance procedures begin; quality of heirs of the beneficiaries, succession capacity, disownment and indignity, transfer of rights and obligations which form the succession patrimony to heirs and legatees, the powers granted to the heirs and the people chosen to execute the will; responsibility for succession debts, succession reserve, calculation of the parts of the inheritance which are awarded to each heir, succession partition.

However, certain aspects were deliberately left out from the enforcement area of this regulation. Thus, according to article 1 second alignment letter h), "the matters regulated by corporate law and the law of other bodies which are organized as companies or not, such as statements included in the articles of association of companies or other such bodies which establish what will happen with the shares 4 in case the members or the holders of these shares die".

As a result, even if de cuius, partner, in a Romanian company, would choose to apply the law of another state to his succession, in regard to the shares he holds, Romanian law will apply and not the foreign law chosen based on the Regulation.

To illustrate the effects of the death of an associate in a company, we will provide a short comparative presentation of the continuance of the collective society with the heirs of the deceased partner as regulated by Law no 31/1990 regarding Romanian companies as opposed to the French Civil Code.

In case of collective society, the first alignment of article 229 of Law no 31/1990 states that "it is dissolved by [...] the death of one of the associates when, due to these causes, the number of the associates was reduced to one". Unlike companies with limited liability, the collective ones do not allow for the possibility to continue their existence as a single partner

4 The European lawmaker considers not only the actions in a restricted manner but also the shares of other types of companies. 


\section{Nicolae}

company5.

Nevertheless, the second alignment states that the company will not be dissolved if, at the time the company was founded, its articles of association mention that the companies can continue to exist with the heirs of the deceased partner. Thus, the articles of association can state the possibility that the heirs of the deceased partner become partners. On the other hand, the same document can state the impossibility to continue the activity with the heirs of the deceased partner. In any of these two cases, the statement contained in the articles of association will produce effects and the company will either continue with the heirs, or it will not continue with the heirs of the deceased partner.

In regard to the succession of an associate, the third alignment of article 202 provides that "in case an amount of shares are acquired by succession, the provisions of the second alignment are not to be applied unless the articles of association state otherwise"; thus, the second alignment states that "the transfer to people outside the company is only allowed if it has been approved by the partners who hold at least three fourths of the shares".

As a consequence, if the article of association does not mention this aspect, such an approval will not be necessary to the heirs as they will become partners. Even if it would state the possibility to continue with the heirs, acquiring the quality of shareholder would be subject to a certain condition, namely the approval of the current shareholders.

A specific case is that in which the article of association contains no mention of whether the company can continue with the heirs of the deceased share holder, but it also does not forbid this aspect, making no mention of it whatsoever.

This situation was the object of a decision of the commercial section of the High Court of Romania which stated that "as the articles of association of the company made no mention of the fact that the activity of the company can continue with the heirs of the deceased partner, the ex wife of the deceased shareholder does not acquire the quality of heir or that of partner"6.

The French Commercial Code states, in article L221-15, that the company dissolves when one of the associates dies. Unlike Law no 31/1990, the death of a single partner, even if the number of the remaining partners is of more than one, is enough to cause the dissolve of the collective company.

According to the same article, if the articles of association state that, in case one of the partners dies the company can continue with the heirs, these mentions will apply, except for the case when, in order to become an associate, the heir will have to be approved by the company.

Thus, the French Commercial Code also states that acquiring the quality of heir depends on the approval of the remaining partners in case the article of association contains

\footnotetext{
5 See HCR, commercial section, decision nr. 1920/2002, în „Romanian Law Review” no 1/2003, p. 83, quoted by S. D. Cărpenaru, Romanian commercial law treaty, Bucharest: Universul Juridic Publishing House, 2012, p. 297, n. 3.

${ }^{6}$ High Court of Romania, commercial section, decision no 4372 of November 13th, 2003 [

$\underline{w w w . s c j . r o]}$. For contrary opinion see doctrine quoted by M. Barbu, Can the heirs continue as associates in a limited responsibility company instead of their deceased author? in „Judicial Courier”, no 1/2009, p. 18, n. 18.
} 
such a provision. Obviously, if it states that continuing the activity with the heirs without requiring approval, the heirs of the deceased person will have the quality of partner as a result of accepting the inheritance.

Neither Law no 31/1990 nor the French Commercial Code make a distinction between the heirs of the deceased associate; they can be legal heirs or legatees, provided the articles of association authorize the continuity of the company with them.

If the company continues with the remaining partners or if, in order to become an associate, the heirs must be approved by the company, but did not receive that approval, the French Commercial Code states that possibility of the heir to become a creditor of the society, thus being entitled to receive the shares of his author.

Similarly, the Romanian lawmaker stated that, in case an associate dies, the collective society must pay to the heirs the share they are entitled to, based on the final accounting balance sheet, within 3 months from the notification regarding the death of the associate7.

As we have seen, both regulations, Law no 31/1990 regarding Romanian companies and the French Commercial Code, are not substantially different in regard to continuing the activity of a collective society, as the principles which govern this matter are essentially the same.

However, the European lawmaker excluded the right or Romanian Companies from the enforcement area of Regulation (EU) no 650/2012 as there is the risk that the economical activity undergone by the Romanian companies is affected by the enforcement of a regulation (even if it is limited to matters of succession) which is different from the laws which regulate the articles of association of companies, as well as the forming and functioning of companies, as the laws are not unified in this matter.

As a result, although de cuius can choose the law which will be applied to his succession, as this law will determine the quality of heir of the beneficiaries, establishing the shares of inheritance which they are entitled to, as well as other rights regarding succession, including the succession rights of the surviving spouse, are the clauses mentioned in the articles of association of companies which establish what will happen in case the associate dies. These are still subject to national law based on which that certain company was created.

Another aspect which should be left out of the enforcement of the Regulations is the patrimonial matter of matrimonial regimes, including matrimonial conventions, as they are known in some legal systems, provided succession matters are not the object of these conventions8.

Although matrimonial regime does not have a direct influence over the successor right of the surviving spouse, determining the entire inheritance entails a liquidation of the matrimonial regime, an operation based on which the surviving spouse can own a smaller or a larger size, depending on the law which applies to the matrimonial regime.

\footnotetext{
7 See S. D. Cărpenaru, Romanian commercial law treaty, Bucharest: Universul Juridic Publishing House, 2012 , p. 297.

8 The matter of matrimonial regimes was explicitly left out from the enforcement of the Regulation (CE) no 593/2008 of the European Parliament of June 17th, 2008 regarding the law which applies to contract obligations (Rome I). Thus, in article 1 second alignment letter c) it is stated that ,the obligations resulted from patrimonial aspects of matrimonial regimes [...] are not subject of enforcement of this regulation $[\ldots]$.
} 


\section{Nicolae}

Thus, it is not only the matrimonial regime chosen by the spouses that can influence the length of the inheritance, but also the law which applies to it.

The matter of which law applies to matrimonial conventions is the object of a project of Council Regulation regarding the competence, the law which applies, the acknowledgement and execution of legal decisions in the matter of matrimonial regimes9.

The need of a regulation which establishes a unified regulation for matrimonial regimes in transnational situations is needed as a result of the increased mobility and the number of marriages which involve at least two member states, as well as the number of divorces and the transnational marriages which dissolve as a result of the death of one of the spouses.

The European Commission issued a communication 10 which became an annex to the suggestion of regulation, by providing an example regarding the partition of goods acquired after marriage, a situation which should be avoided once this new regulation is passed.

According to this example, a Greek-Hungarian couple was married in Greece and lived there for three years. After this time, the two decide tot move to Hungary. After two years in Hungary, the marriage was dissolved.

On one hand, according to Greek law, by applying the regulations regarding conflicting laws, the liquidation of the matrimonial regime is subject to Greek law, as the liaison factor is the common residence of the spouses at the time of marriage. On the other hand, by applying the regulations regarding conflicting laws in the Hungarian system of law, the liquidation of the matrimonial regime should be governed by Hungarian law, as the liaison factor is the common residence of the spouses at the time of divorce.

As a consequence, if the Hungarian spouse estimates that the law of his state would be favorable, by protecting its interested in a privileged manner, he will file a complaint before the Hungarian court and, according to current regulation, the spouse who is more informed can initiate this procedure first, thus placing the other spouse in an inferior position.

This is why the European lawmaker chose to regulate these matters in order to ensure security and judicial predictability in the matter of matrimonial regimes, thus thinking that these objectives could not be achieved if the member states would benefit from appreciation in including the suggested regulation in national law11.

We must also state that this regulation, much like the one regarding succession, does not aim to unify internal law in the matter of matrimonial regimes, which are different from one member state to the other, but to ensure predictability in regard to the law which applies to all the goods of a couple, regardless of where these goods are, thus avoiding to divide the law which applies12 to the matrimonial regime of a couple, namely the enforcement of

\footnotetext{
9 European Commission, Suggestion of regulation regarding the competence, the law which applies, acknowledgement or the execution of legal decisions in the matter of matrimonial regimes, Brussels, 16.03.2011, COM (2011) 126 final.

${ }^{10}$ European Commission, Notice of the Commission to the European Parliament, Council, the European Economical and Social Committee and the Regions' Committee - Eliminating uncertainty in regard to the patrimonial rights of international couples, $\operatorname{COM}(2011) 125$ final, Brussels, 16.3.2011, p. 2-3.

${ }_{11}$ European Commission, COM (2011) 126 final, p. 5.

12 European Commission, COM (2011) 126 final, p. 8.
} 
national laws which are different in regard to goods subject to matrimonial regime, thus causing a high degree of legal insecurity.

According to article 15 of the suggested regulation, "the law which applies to matrimonial regime [...] is applied to all the goods owned by the spouses"; point $13 \mathrm{~d}$ states that the notion of matrimonial regime should comprise all provision of patrimonial law which is applied between spouses and in their relation to third parties, after marriage and after the marriage ends13. Patrimonial law provisions should include not only mandatory provisions of the law which applies, but also certain facultative provisions which can be agreed upon by spouses based on the law which applies.

After this regulation is enforced, the spouses or the future spouses will be able to choose the law which applies to their matrimonial regime. However, this choice will be limited to one of the following laws: either the law of the state where the future spouses have their common residence, or the law of the state where one of the spouses or future spouses has its residence at the time of making this choice, or the law of the state whose citizen one of the spouses is at the time of making this choice. As a result, the spouses are given the possibility to choose the law which will apply, but this choice is limited in order to avoid the situation in which the spouses would be tempted to choose a law which would have nothing to do with their marriage.

There is also the situation in which the spouses do not expressly choose the law which applies to the their matrimonial regime; in this case, according to article 17, the law which applies is either the law of the state where the spouses or future spouse have their first common residence or the law of the state whose citizen one of the spouses is at the time of marriage (this will not apply if the spouses have more than one common citizenship) or the law of the state to which the spouses have the strongest connection with, considering all circumstances, including the place where the marriage was concluded.

Thus, the European lawmaker established a series of objective factors which will be applied based on their importance (the first common residence, common citizenship, the state to which the couple has the strongest connection with) in order to determine the law which applies, as the chosen criteria ensure a balance between the reality of the couple's life and the need to easily identify the law which applies to the matrimonial regime in regard to the spouses as well as third parties 14 .

The law which applies to the matrimonial regime will regulate, among others, the partition of the spouses' goods in different categories, before and after marriage; the responsibility for the debts of the other partner, the power to administrate the goods of the other spouse during marriage, the dissolve of the marriage, the liquidation of the matrimonial regime and the partition of goods in case the marriage ends, the effects of the matrimonial

\footnotetext{
${ }^{13}$ European Parliament, Report regarding the suggestion of regulation regarding the competence, the law which applies, acknowledgement or the execution of legal decisions in the matter of matrimonial regimes, A7-0253/2013, 20.08.2013, p. 9-10.

14 European Commission, Suggestion of regulation regarding the competence, the law which applies, acknowledgement or the execution of legal decisions in the matter of matrimonial regimes, Brussels, 16.03.2011, COM (2011) 126 final, p. 8.
} 


\section{Nicolae}

regime on the legal relation between one of the spouses and a third party, as well as the validity of the matrimonial regime 15 .

However, some aspects, such as the residence of the family, will continue to be regulated by national law, regardless of the law which applies to the matrimonial regime according to the suggested regulation, as article 22 states that the provisions of the regulation will not have influence over the mandatory provision which must be respected by a certain member state in order to protect its public interests.

As a result, even if the spouses or future spouses who reside in Romania would choose another law for their matrimonial regime, the provisions of the Romanian Civil Code would continue to protect the family residence as the spouse who is not owner will be able to request an annulment of the act by which the other spouse administered the family residence [alignment 4 of article 322 of the Civil Code], even if the law which applies to the matrimonial regime would not state such a sanction.

Much like the law which applies to succession, a choice which can be modified or revoked according to the fourth alignment of article 22 of the Regulation (EU) no 650/2012, the law which applies to the matrimonial regime can be changed at any time during the course of marriage. Thus, as the law is not immutable and the law which applies to matrimonial regimes may not correspond to the legitimate expectances of the spouses, they will be able to choose another law for their matrimonial regime, but the choice is limited to the law of the usual residence at the time the choice was made or the law of a state whose citizen one of the spouses is at the time of making this choice.

Another interesting aspect is that the spouses will be able to modify the law which applies to their matrimonial regime in retroactive, without causing prejudice to the right of third parties which resulted from enforcing the previous law and without affecting the validity of the previous acts concluded based on the law which applied at that certain time16.

Equality between spouses is a legal desiderate rather than a practical reality, as the Commission for women's rights and gender equality recommended a series of amendments 17 among which one requires our attention.

Thus, as it is possible that a vulnerable spouse did not make a free and correct matrimonial choice in regard to property due to specific circumstances, like financially depending on the other spouse, a difference in salary, the lack of access to information or legal council or circumstances regarding illness or domestic violence, the choice of the law which applies to matrimonial regime should be preceded by the correct information provided to each of the spouses by legal council, especially in regard to the legal consequences of this

\footnotetext{
${ }^{15}$ European Parliament, Report regarding the suggestion of regulation regarding the competence, the law which applies, acknowledgement or the execution of legal decisions in the matter of matrimonial regimes,

A7-0253/2013, 20.08.2013, p. 34. Also, according to article $15 \mathrm{a}$, the law will be applies regardless of whether it is the law of a member state or not-Ibidem, p. 16.

16 European Parliament, Report regarding the suggestion of regulation regarding the competence, the law which applies, acknowledgement or the execution of legal decisions in the matter of matrimonial regimes, A7-0253/2013, 20.08.2013, p. 36.

17 Notice from the Commission for women's rights and gender equality destined for the Commission for legal affairs regarding the suggestion of regulation regarding the competence, the law which applies, acknowledgement or the execution of legal decisions in the matter of matrimonial regimes, 7.05.2012.
} 
choice.

On one hand, we believe that such council is to be desired; however, we believe that it is unlikely that this could effectively prevent the situations in which the vulnerable spouse makes a less fortunate choice in regard to the matrimonial regime. On the other hand, once the Regulation regarding the competence, the law which applies, acknowledgement or the execution of legal decisions in the matter of matrimonial regimes is passed, the spouses or future spouses will be able to plan the patrimonial effects of the matrimonial regime more carefully.

As we have seen, one the Regulation (EU) no 650/2012 is enforced, de cuius can choose in favor of another law. Also, after the passing and enforcement of the regulation regarding the free choice of the law which applies to matrimonial regimes, new possibilities will be available in regard to planning patrimonial effects.

As a conclusion, both theoreticians and the practitioners of law within the EU will have to apply not only their national law, but they should also become more familiar with the regulations which are in force in other member states in order to meet the needs of counseling the transnational couples.

\section{Bibliography:}

M. Barbu, Can the heirs continue as associates in a limited responsibility company instead of their deceased author? in „Judicial Courier”, no 1/2009,

S. D. Cărpenaru, Romanian commercial law treaty, Bucharest: Universul Juridic Publishing House, 2012.

V. D. Zlătescu, Panorama of the great contemporary systems of law, „Continent XXI” Publishing House, Bucharest, 1994.

European Commission, Notice of the Commission to the European Parliament, Council, the European Economical and Social Committee and the Regions' Committee - Eliminating uncertainty in regard to the patrimonial rights of international couples, $\mathrm{COM(2011)} 125$ final, Brussels, 16.3.2011.

European Commission, Suggestion of regulation regarding the competence, the law which applies, acknowledgement or the execution of legal decisions in the matter of matrimonial regimes, Brussels, 16.03.2011, COM (2011) 126 final.

European Parliament, Report regarding the suggestion of regulation regarding the competence, the law which applies, acknowledgement or the execution of legal decisions in the matter of matrimonial regimes, A7-0253/2013, 20.08.2013. 